\title{
Chemical and microbiological changes in the soil mediated by different vegetative coverings in a Natal orange orchard
}

\section{Alterações químicas e microbiológicas do solo mediada por diferentes coberturas vegetais em pomar de laranjeira 'Natal'}

Gabriel Danilo Shimizu*; Jean Carlo Baudraz de Paula ${ }^{1}$; Adriana Pereira da Silva²; Camilla de Andrade Pacheco ${ }^{3}$; Fernando Alves de Azevedo ${ }^{4}$; Leandro Simões Azeredo Gonçalves ${ }^{2}$; Carmen Silvia Vieira Janeiro Neves ${ }^{2}$

\section{Highlights}

Urochloa species improve the chemical and microbiological attributes of the soil.

There is no short-term effect of Urochloa species on Natal orange plants.

Glyphosate applied to the total area created a negative response in soil quality.

\begin{abstract}
Proper soil cover management for citrus cultivation can contribute to increased productivity and improved soil quality. This study examined five different vegetative coverings [Urochloa brizantha; U. decumbens, $U$. ruziziensis, spontaneous vegetation, and herbicide application (glyphosate) in the total area] in the inter rows of a Natal orange orchard [Citrus sinensis (L.) Osbeck] grafted on the Swingle citrumelo (C. paradisi $\times$ Poncirus trifoliata). Their effects on the microbiological and chemical attributes of the soil and the vegetative development in the orchard were examined. Chemical $\left(\mathrm{Ca}^{2+}, \mathrm{Mg}^{2+}, \mathrm{K}^{+}, \mathrm{P}, \mathrm{pH}, \mathrm{H}+\mathrm{Al}, \mathrm{CEC}_{\mathrm{pH} 7^{\prime}}\right.$ base saturation, and $\mathrm{OM}$ ) and microbiological (carbon and nitrogen of microbial biomass, basal respiration, and metabolic quotient) soil attributes in the rows and inter-rows were evaluated for the orchard in 2018 and 2019. There was a significant difference for most variables in the 2 years studied, emphasizing 2019 for microbiological parameters and $\mathrm{OM}$, with the latter being $14.8 \%$ lower in the treatment with glyphosate in the total area compared to the treatment with spontaneous vegetation. The results showed the benefits of vegetation

1 Students of the PhD of the Postgraduate Program in Agronomy, Universidade Estadual de Londrina, UEL, Londrina, PR, Brazil. E-mail: shimizu@uel.br, jc_baudraz@live.com

2 Profs. Drs., Agronomy Departament, UEL, Londrina, PR, Brazil. E-mail: drikapera@yahoo.com.br, leandrosag@uel.br, csvjneve@uel.br

3 Researcher, Fundo de Defesa da Citricultura, Fundecitrus, Araraquara, PR, Brazil. E-mail: camilla_andrade@yahoo. com.br

${ }^{4}$ Researcher, Centro de Citricultura Sylvio Moreira, Instituto Agronômico de Campinas, CCSM-IAC, Cordeirópolis, SP, Brazil. E-mail: fernando@ccsm.br

* Author for correspondence
\end{abstract}


cover with brachiaria in inter-rows of the Natal sweet orange orchard in the chemical and microbiological attributes of the soil, especially in carbon and nitrogen of the microbial biomass.

Key words: Conservation agriculture. Citrus sinensis. Glyphosate. Urochloa.

\section{Resumo}

O manejo adequado da cobertura do solo para o cultivo de citros pode contribuir com o aumento da produtividade e melhoria da qualidade do solo. Esse trabalho estudou cinco diferentes coberturas vegetais (Urochloa brizantha; U. decumbens, U. ruziziensis, vegetação espontânea e aplicação de herbicida (glifosato) em área total) na entrelinha do pomar de laranjeira 'Natal' [Citrus sinensis (L.) Osbeck] enxertada em citrumeleiro 'Swingle' (C. paradisi $\times$ Poncirus trifoliata) nos atributos microbiológicos e químicos do solo, bem como a influência desse manejo no desenvolvimento vegetativo do pomar. Foram avaliados os atributos químicos $\left(\mathrm{Ca}^{2+}, \mathrm{Mg}^{2+}, \mathrm{K}^{+}, \mathrm{P}, \mathrm{pH}, \mathrm{H}+\mathrm{Al}, \mathrm{CTC}{ }_{\mathrm{pH} 7}\right.$ saturação por bases e $\mathrm{MO}$ ) e microbiológicos (carbono e nitrogênio da biomassa microbiana, respiração basal e quociente metabólico) do solo na linha e na entrelinha do pomar, nos anos de 2018 e 2019. Houve diferença significativa para a maioria das variáveis nos dois anos estudados, com destaque no ano de 2019 para as variáveis microbiológicas e na MO, sendo esse último, 14,8\% menor no tratamento com glifosato em área total em relação ao tratamento com vegetação espontânea. Os resultados permitiram evidenciar os benefícios da cobertura vegetal com as braquiárias na entrelinha do pomar de laranjeira doce 'Natal' nos atributos químicos e microbiológicos do solo, sobretudo no carbono e nitrogênio da biomassa microbiana.

Palavras-chave: Agricultura de conservação. Citrus sinensis. Glifosato. Urochloa.

\section{Introduction}

Sweet orange trees (Citrus sinensis L.) are the most important citrus group globally, with an emphasis in Brazil, which is the largest producer of this fruit, with an area of 589610 ha, equivalent to 17.1 million tons produced (Food and Agriculture Organization of the United Nations [FAOSTAT], 2019). The success of this production is mainly linked to the adoption of sustainable management practices, such as the use of cover crops and ecological cutters (Ribeiro, Jaime, \& Ventura, 2017), reducing erosion and soil disturbance, and direct exposure to the sun and raindrops (Azevedo, Rossetto, Schinor, Martelli, \& Pacheco, 2012). Consequently, the implementation of conservation agriculture (CA) of the FAO (Food and Agriculture Organization), which involves a minimum preparation of the soil the use of cover crops, and a diversity of species cultivated in sequence (crop rotation) or in association (consortium) (Food and Agriculture Organization [FAO], 2017), has been the object of study in several works, reducing productivity losses and benefiting citriculture.

Therefore, the most effective and widely used method to monitor sustainable management practices is assessing soil quality through chemical, physical, and microbiological indicators. It should be noted that microbiological indicators are considered the most sensitive because they demonstrate recent changes in biomass and microbial activity in the soil, easily capturing the transformations that occur, according to the different systems (Willekens, Vandecasteele, Buchan, \& Neve, 2014). 
Consequently, CA uses cover crops as one of the pillars to its application, especially in relation to the production of cover plant biomass in the inter-rows of orchards, with a focus on evaluations of different cover species, water storage capacity, and weed control (Azevedo et al., 2012; Martinelli, Monquero, Fontanetti, Conceição, \& Azevedo, 2017). Thus, the brachiaria species are good options for plant cover, especially the hairy brachiaria (Urochloa ruziziensis Germain \& Evrard) because it displays low interference in the development of citrus plants compared to other species, such as $U$. decumbens and $U$. brizantha.

Urochloa species are characterized by the production of large amounts of biomass and a vigorous, abundant, and deep root system, which is often used in pastures, in intercropping with other crops, such as corn (Baptistella, Andrade, Favarin, \& Mazzafera, 2020), or as plant intercalation in perennial crops, such as coffee (B. M. Silva et al., 2019) and citrus (Martinelli et al., 2017). In the case of perennial crops, the forage can be sown in the inter-rows in the total area before or after the establishment of the crop and must be controlled to maintain at least $0.5 \mathrm{~m}$ distance from the crop, usually with the use of herbicides or brush cutters, to avoid competition for resources and facilitate crop management (Martinelli et al., 2017; Baptistella et al., 2020).

Brachiaria can exploit large volumes of soil and absorb substantial amounts of nutrients in soil regions where the main crop does not have the capacity (Rosolem et al., 2017). Additionally, it allows the activation of several processes that affect soil aggregation and increase cation retention capacity, nutrient storage, adsorption, complexation of compounds, nutrient cycling, atmospheric carbon sequestration, and consequently, the biological activity of the soil (Martorano et al., 2009; Martins, Gonçalves, \& Silva, 2016; D. S. Almeida \& Rosolem, 2016; Nuñez et al., 2018). For example, certain root exudates from brachiaria can reduce nitrogen (N) losses through leaching and denitrification, preventing the nitrification process from occurring (Byrnes et al., 2017; Nuñez et al., 2018). In the case of phosphorus (P), exudates can mobilize recalcitrant forms of soil $P$, making it available for plant uptake (Janegitz, Inoue, \& Rosolem, 2013; D. S. Almeida \& Rosolem, 2016). However, despite benefits, spontaneous vegetation or cover crops can harm the main crop if poorly managed because of competition for water, light, and nutrients (Balota \& Auler, 2011).

The objective of this study was to analyze the microbiological and chemical attributes of the soil in the rows and interrows of a newly planted Natal orange orchard subjected to different management systems and the influence of this management on the vegetative development of plants.

\section{Material and Methods}

The experiment was conducted in the municipality of Londrina, Paraná State, in a plot with dimensions of $120 \mathrm{~m} \times 40 \mathrm{~m}$ located at $23^{\circ} 20^{\prime} 23^{\prime \prime} \mathrm{S}$ and $51^{\circ} 12^{\prime} 32^{\prime \prime} \mathrm{W}$, at $532 \mathrm{~m}$ altitude, in a 3-year-old orchard of the Natal orange variety [Citrus sinensis (L.) Osbeck] grafted on the Swingle citrumelo [C. paradise Macfad. Duncan $\times$ Poncirus trifoliata (L.) Raf.], with a spacing of $7.0 \times 3.0 \mathrm{~m}$.

According to the classification proposed by Köppen, the climate of the region is the Cfa subtropical mesothermic type with hot summers and infrequent frosts. 
The average annual precipitation is $1632 \mathrm{~mm}$ with frequent rain in the summer months and without a defined dry season. The average annual temperature is $21.2^{\circ} \mathrm{C}$, with an average maximum of $27.4^{\circ} \mathrm{C}$, an average minimum of $16.2^{\circ} \mathrm{C}$, and an average relative humidity $(\mathrm{RH})$ of $70.5 \%$ (Instituto de Desenvolvimento Rural do Paraná [IDR-PR], 2019). The soil is classified as Eutroferric Red Latosol (Empresa Brasileira de Pesquisa Agropecuária [EMBRAPA], 2018), positioned on a half slope, and well-drained. The average maximum, minimum, and average temperatures throughout the experiment were $27.79,16.92$, and $21.71^{\circ} \mathrm{C}$, respectively, and the average $\mathrm{RH}$ was $72.24 \%$.

The soil in the experimental area was analyzed for chemical attributes $(0-20 \mathrm{~cm})$, with the following results: $\mathrm{K}^{+}=0.74 \mathrm{cmol}_{\mathrm{c}} \mathrm{dm}^{-3}$; $\mathrm{Ca}^{2+}=12.2 \mathrm{cmol}_{\mathrm{c}} \mathrm{dm}^{-3} ; \mathrm{Mg}^{2+}=3.8 \mathrm{cmol}_{\mathrm{c}} \mathrm{dm}^{-3}$; $\mathrm{P}\left(\right.$ Mehlich 1) $=21.7 \mathrm{mg} \mathrm{dm}^{-3} ; \mathrm{Al}^{3+}=0.0 \mathrm{cmol}$ $\mathrm{dm}^{-3} ; \mathrm{H}+\mathrm{Al}=2.5 \mathrm{cmol}_{\mathrm{c}} \mathrm{dm}^{-3} ; \mathrm{pH} \mathrm{CaCl}_{2}=6.6 ; \mathrm{MO}$ $=4.2 \% ; \mathrm{CTC}=16.7 \mathrm{cmol}_{\mathrm{c}} \mathrm{dm}^{-3}$; and $\mathrm{V}=87.0 \%$. Fertilization was conducted in accordance with the technical recommendations for citrus cultivation (Mattos et al., 2014) three times a year. The application of $3.0 \mathrm{~kg}$ of simple superphosphate $\left(20 \%\right.$ of $\left.\mathrm{P}_{2} \mathrm{O}_{5}\right)$ was conducted in October 2018 and 2019, and four applications of $1.8 \mathrm{~kg}$ of ammonium sulfate ( $20 \%$ of $N$ ) occurred during the year, totaling $7.2 \mathrm{~kg}$. The control of pests and diseases was conducted through monitoring and, when necessary, phytosanitary products for control were applied. The orchard was not irrigated and depended on rainfall for water.

The trial was located in a completely randomized model with five treatments, represented by different coverings in inter-rows of the orchard, with three species of brachiaria (U. brizantha [BRABR], U. decumbens [BRADC] and $U$. ruziziensis [BRARU]), spontaneous vegetation (SV; with a predominance of
Digitaria insularis), and application of herbicide (glyphosate) to the total area (GLY).

The sowing of brachiaria was broadcast in December 2016 in the inter-rows of the orchard. The planting line was defined based on the crown projection, approximately $50 \mathrm{~cm}$ from the stem of the Natal orange plants. Soil management in the orchard line consisted of applying glyphosate $\left(480 \mathrm{~g} \mathrm{~L}^{-1}\right)$ five times a year, depending on the level of infestation. The plots were mowed five times in 2018 and three times in 2019 with the aid of a conventional tractored mower, leaving the straw on the ground.

Each plot consisted of 12 Natal orange plants, distributed in three rows (four plants in each row), with the two central plants considered useful for evaluation purposes. Soil samples were collected in January 2018 and 2019 in the $0-20 \mathrm{~cm}$ deep layer, separating the row and the inter-rows, at four different points, totaling 120 samples, which were analyzed individually.

\section{Soil chemical analysis}

The $\mathrm{pH}\left(0.01 \mathrm{~mol} \mathrm{~L}^{-1} \mathrm{CaCl}_{2}\right)$ and the potential acidity $(\mathrm{H}+\mathrm{Al})$ were determined using an SMP buffer solution; $\mathrm{K}^{+}$and $\mathrm{P}$ were extracted with the Mehlich-1 extraction solution. Flame photometry was used to determine $\mathrm{K}^{+}$, and colorimetry was used for $\mathrm{P}$ (Tedesco, Gianello, Bissani, Bohnen, \& Volkweiss, 1995). Calcium and magnesium were analyzed using an atomic absorption spectrophotometer (Welz, \& Sperling, 2008). Organic carbon was determined according to the potassium dichromate oxidation and ferrous sulfate titration methodology described by Walkley and Black (1934). The cation exchange capacity $\left(\mathrm{CTC}_{\mathrm{pH} 7}\right)$ and base saturation (V\%) were calculated from the primary analytical results. 


\section{Soil microbiological analysis}

Microbial biomass carbon was determined using the fumigation-extraction method (Vance, Brookes, \& Jenkinson, 1987). The samples were read using a spectrophotometer at $495 \mathrm{~nm}$. The correction factor, $\mathrm{Kc}$, of 0.41 was used to calculate the $\mathrm{C}$ of the microbial biomass. The results were expressed in micrograms of $\mathrm{C}$ per $\mathrm{kg}$ of dry soil (mg C kg-1 of soil).

The $\mathrm{N}$ content in the extracts was determined by wet digestion in a digester block at $350^{\circ} \mathrm{C}$ with concentrated sulfuric acid $\left(\mathrm{H}_{2} \mathrm{SO}_{4}\right)$ (J. M. Bremer, 1965), and the colorimetric determination of ammoniacal $\mathrm{N}$ $\left(\mathrm{N}-\mathrm{NH}_{4}\right)$ was achieved using the indophenol blue method (Feije \& Anger, 1972). The reading was performed with a spectrophotometer at $630 \mathrm{~nm}$, and the results were expressed in $\mathrm{mg}$ $\mathrm{N} \mathrm{kg}^{-1}$ of soil.

The respiratory activity of microbial biomass, or basal soil respiration (RBS), was determined according to the methodology of Jenkinson and Powlson (1976) as adapted by E. E. Silva, Azevedo and De-Polli (2007), and expressed in $\mathrm{mg}$ of $\mathrm{C}-\mathrm{CO}_{2} \mathrm{~kg}^{-1}$ soil $\mathrm{h}^{-1}$. The metabolic quotient $\left(q \mathrm{CO}_{2}\right)$ was calculated using the direct relationship between the $\mathrm{C}-\mathrm{CO}_{2}$ released and the carbon in the microbial biomass.

Vegetative development of Natal orange plants

The vegetative development of the plants was measured with the aid of a graduated ruler, obtaining the height and canopy diameter, and the canopy volume (V) was calculated based on the formula (Mendel, 1956):

$$
V=\frac{2}{3} \pi R^{2} H
$$

where $\mathrm{R}$ is the mean radius of the crown, and $\mathrm{H}$ represents the height of the plant.

\section{Statistical analysis}

The results were subjected to deviance analysis using Wald's $\mathrm{F}$ test, considering the mixed linear model, to group line and spacing samples. The line/line interaction was conducted with management and isolated factors considered fixed effects, and the plot considered a random effect. When significant for interaction, row and inter-rows were analyzed separately; however, when not significant, both were grouped and analyzed together. When there was a significant effect, the means were compared using Tukey's test $(p \leq 0.05)$. For the variable vegetative development, the data were subjected to an analysis of variance (ANOVA) and, when significant, the means were compared using Tukey's test $(p \leq 0.05)$.

Hierarchical cluster analysis was performed by calculating the Euclidean distance between the treatments studied for the set of 13 response variables, using the UPGMA method to obtain clusters of similar treatments. With this analysis, we sought to verify the similarities among the variables analyzed and the treatments studied from homogeneous clusters represented in a dendrogram of joint similarity between the 2 years to visualize the similarity in the results.

A principal component analysis (PCA) was conducted to reduce the large number of variables to a smaller set, identifying which variables belong to which components and how much each variable explains each 
component. The null hypothesis of the correlation matrix as an identity matrix was analyzed using Bartlett's sphericity test ( $p \leq$ 0.05). All analyses were performed using $\mathrm{R}$ software (R Core Team [R], 2019).

\section{Results and Discussion}

\section{Soil chemical attributes}

The deviance analysis of the chemical properties of the soil in the years 2018 and 2019 indicated a significant difference in the interaction between factors for most variables; thus, whenever possible, rows and inter-rows were analyzed separately (Table 1). Regarding the $\mathrm{Ca}^{2+}$ content of the soil, lower values were observed in inter-rows of the orchard with BRABR in the years 2018 (4.2 $\left.\mathrm{cmol}_{\mathrm{c}} \mathrm{dm}^{-3}\right)$ and $2019\left(6.5 \mathrm{cmol}_{\mathrm{c}} \mathrm{dm}^{-3}\right)$ and higher values with BRARU in $2018\left(5.1 \mathrm{cmol}_{\mathrm{c}}\right.$ $\mathrm{dm}^{-3}$ ) and GLY in $2019\left(9.0 \mathrm{cmol}_{\mathrm{c}} \mathrm{dm}^{-3}\right.$ ) (Table 1). The increase in calcium content from 2018 to 2019 was caused by the application of simple superphosphate in the total area of the orchard.

Despite the statistical difference between the vegetative coverings in 2018, all calcium contents were between the high and very high classes, according to Moreira et al. (2019). This difference was more evident in 2019 when the treatment without covering (GLY) had higher content because calcium is not very mobile in the soil. In this sense, it is worth mentioning that the cycling potential of any plant species depends on the accumulation of nutrients and its rate of waste decomposition, and the time it remains in the field, as it can enable greater accumulation of nutrients (Baptistella et al., 2020). Thus, although it presented a priori, few differences in the availability of calcium in the soil occurred, as in Azevedo et al. (2020). We emphasize that the accumulation of nutrients and their release is a slow process and, consequently, changes in productivity and quality of sweet oranges will only be noticeable in the long term.

\section{Table 1}

Calcium, magnesium, potassium, potential acidity, pH, phosphorus, CTCpH7, base saturation (V), and OM in a Natal orange orchard under different land cover management. BRABR: $U$. brizantha, BRADC: $U$. decumbens, BRARU: U. ruziziensis, GLY: Glyphosate in total area, SV: spontaneous vegetation in the row (R) and inter-row (IR) of planting (Londrina/PR, 2019)

\begin{tabular}{|c|c|c|c|c|c|c|c|c|c|}
\hline \multirow[b]{2}{*}{ Year } & \multirow[b]{2}{*}{ Position } & BRABR & BRADC & BRARU & GLY & SV & \multicolumn{3}{|c|}{ p-value of Wald's F Test } \\
\hline & & \multicolumn{5}{|c|}{ Calcium $\left(\mathrm{cmol}_{\mathrm{c}} \mathrm{dm}^{-3}\right)$} & $A \times B$ & Position (A) & Cover (B) \\
\hline \multirow{2}{*}{2018} & IR & $4.15 b$ & $4.97 \mathrm{ab}$ & $5.07 a$ & $4.57 \mathrm{ab}$ & $4.87 a b$ & \multirow{2}{*}{0.0013} & \multirow{2}{*}{$<0.0001$} & \multirow{2}{*}{0.3200} \\
\hline & $\mathrm{R}$ & $4.08 \mathrm{a}$ & $3.68 \mathrm{a}$ & $3.64 \mathrm{a}$ & $3.67 \mathrm{a}$ & $4.37 \mathrm{a}$ & & & \\
\hline \multirow{2}{*}{2019} & IR & $6.46 \mathrm{~b}$ & $6.66 \mathrm{ab}$ & $7.88 \mathrm{ab}$ & $9.04 \mathrm{a}$ & $8.74 a b$ & \multirow{2}{*}{$<0.0001$} & \multirow{2}{*}{0.042} & \multirow{2}{*}{0.388} \\
\hline & $\mathrm{R}$ & $6.28 \mathrm{a}$ & $6.34 \mathrm{a}$ & $6.68 \mathrm{a}$ & $5.45 a$ & $4.62 \mathrm{a}$ & & & \\
\hline \multicolumn{10}{|c|}{ Magnesium $\left(\mathrm{cmol}_{\mathrm{c}} \mathrm{dm}^{-3}\right)$} \\
\hline 2018 & $\begin{array}{c}\text { IR } \\
\mathrm{R}\end{array}$ & 2.91 & 2.99 & 2.95 & 2.98 & 3.03 & 0.5053 & $<0.001$ & 0.7976 \\
\hline
\end{tabular}

continue... 
continuation...

\begin{tabular}{|c|c|c|c|c|c|c|c|c|c|}
\hline 2019 & $\begin{array}{l}\text { IR } \\
\mathrm{R}\end{array}$ & $\begin{array}{c}2.60 a b \\
2.44 a\end{array}$ & $\begin{array}{l}2.70 a b \\
2.14 a b\end{array}$ & $\begin{array}{c}2.21 \mathrm{~b} \\
2.42 \mathrm{ab}\end{array}$ & $\begin{array}{l}3.05 a \\
2.50 a\end{array}$ & $\begin{array}{l}2.86 a \\
1.83 b\end{array}$ & 0.029 & 0.145 & 0.004 \\
\hline \multicolumn{10}{|c|}{ Potassium $\left(\mathrm{cmol}_{\mathrm{c}} \mathrm{dm}^{-3}\right)$} \\
\hline \multirow{2}{*}{2018} & IR & $1.51 \mathrm{a}$ & $1.21 \mathrm{~b}$ & $1.20 \mathrm{~b}$ & $1.04 \mathrm{~b}$ & $1.16 \mathrm{~b}$ & \multirow{2}{*}{0.0004} & \multirow{2}{*}{$<0.0001$} & \multirow{2}{*}{0.1420} \\
\hline & $\mathrm{R}$ & $0.74 a$ & $0.90 \mathrm{a}$ & $0.98 \mathrm{a}$ & $0.89 a$ & $0.83 a$ & & & \\
\hline \multirow{2}{*}{2019} & IR & $1.30 \mathrm{~b}$ & $1.59 \mathrm{a}$ & $1.28 \mathrm{~b}$ & $1.32 \mathrm{~b}$ & $1.31 \mathrm{~b}$ & \multirow{2}{*}{0.0010} & \multirow{2}{*}{0.5690} & \multirow{2}{*}{0.0110} \\
\hline & $\mathrm{R}$ & $1.42 a b$ & $1.23 \mathrm{bc}$ & $1.14 \mathrm{c}$ & $1.48 \mathrm{a}$ & $1.28 \mathrm{abc}$ & & & \\
\hline \multicolumn{10}{|c|}{ Phosphorus (mg dm³) } \\
\hline 2018 & $\begin{array}{l}\text { IR } \\
\mathrm{R}\end{array}$ & 16.46 & 19.46 & 18.98 & 14.26 & 19.91 & 0.2725 & 0.6699 & 0.0561 \\
\hline & IR & $32.22 \mathrm{a}$ & $22.60 \mathrm{~b}$ & $25.30 \mathrm{ab}$ & $26.94 a b$ & $23.42 b$ & & & \\
\hline 2019 & $\mathrm{R}$ & $26.36 \mathrm{a}$ & $31.90 \mathrm{a}$ & $31.66 \mathrm{a}$ & $28.86 a$ & 30.98 a & 0.0020 & 0.2210 & 0.1060 \\
\hline \multicolumn{10}{|c|}{$\mathrm{H}+\mathrm{Al}\left(\mathrm{cmol}_{\mathrm{c}} \mathrm{dm}^{-3}\right)$} \\
\hline 2018 & $\begin{array}{l}\text { IR } \\
\mathrm{R}\end{array}$ & $3.26 \mathrm{a}$ & $3.23 \mathrm{a}$ & $3.03 \mathrm{a}$ & $2.96 \mathrm{a}$ & $2.51 \mathrm{~b}$ & 0.0612 & $<0.0001$ & $<0.0001$ \\
\hline 2019 & IR & $3.53 a$ & $3.08 a b$ & $3.41 \mathrm{a}$ & $2.63 a b$ & $2.27 \mathrm{~b}$ & $<\cap \cap \cap \cap 1$ & & \\
\hline 2019 & $\mathrm{R}$ & $3.11 \mathrm{~b}$ & $4.10 a b$ & $4.10 a b$ & $3.30 \mathrm{~b}$ & $4.74 \mathrm{a}$ & -0.0001 & 0.1000 & 0.0340 \\
\hline \multicolumn{10}{|c|}{$\mathrm{pH} \mathrm{CaCl}{ }_{2}$} \\
\hline 2018 & $\begin{array}{c}\text { IR } \\
\mathrm{R}\end{array}$ & $6.42 a b$ & $6.26 \mathrm{~b}$ & $6.51 \mathrm{ab}$ & $6.25 b$ & $6.63 a$ & 0.5638 & $<0.0001$ & 0.0027 \\
\hline 2019 & IR & $5.79 \mathrm{bc}$ & $5.88 \mathrm{bc}$ & $5.72 \mathrm{c}$ & $6.21 \mathrm{ab}$ & $6.32 \mathrm{a}$ & & & \\
\hline 2015 & $\mathrm{R}$ & $5.77 \mathrm{a}$ & $5.51 a b$ & $5.74 \mathrm{a}$ & $5.82 \mathrm{a}$ & $5.32 b$ & $<0.001$ & 0.2380 & 0.0380 \\
\hline \multicolumn{10}{|c|}{$\mathrm{CTC}_{\mathrm{pH}}\left(\mathrm{cmol}_{\mathrm{c}} \mathrm{dm}^{-3}\right)$} \\
\hline 2018 & $\begin{array}{l}\text { IR } \\
\mathrm{R}\end{array}$ & $11.38 a b$ & 11.99 a & $11.41 \mathrm{ab}$ & 11.02 b & $11.16 \mathrm{ab}$ & 0.8098 & $<0.0001$ & 0.0472 \\
\hline \multirow{2}{*}{2019} & IR & $13.89 a$ & $14.02 \mathrm{a}$ & 14.78 a & 16.05 a & $15.21 \mathrm{a}$ & \multirow{2}{*}{0.0230} & \multirow{2}{*}{0.0280} & \multirow{2}{*}{0.3450} \\
\hline & $\mathrm{R}$ & $13.25 \mathrm{a}$ & $13.80 \mathrm{a}$ & $14.33 \mathrm{a}$ & $12.72 \mathrm{a}$ & $12.47 \mathrm{a}$ & & & \\
\hline \multicolumn{10}{|c|}{ V (\%) } \\
\hline 2018 & $\begin{array}{c}\text { IR } \\
\mathrm{R}\end{array}$ & 71.44 b & 69.99 b & $73.09 \mathrm{ab}$ & $72.52 \mathrm{ab}$ & $77.22 \mathrm{a}$ & 0.0921 & $<0.0001$ & 0.0068 \\
\hline \multirow{2}{*}{2019} & IR & $74.02 \mathrm{~b}$ & $77.62 \mathrm{ab}$ & $76.80 \mathrm{ab}$ & $83.59 a b$ & 85.00 a & \multirow{2}{*}{0.0020} & \multirow{2}{*}{0.1310} & \multirow{2}{*}{0.2390} \\
\hline & $\mathrm{R}$ & $76.21 \mathrm{a}$ & $69.68 \mathrm{ab}$ & $71.47 \mathrm{ab}$ & $73.81 \mathrm{a}$ & $61.94 \mathrm{~b}$ & & & \\
\hline \multicolumn{10}{|c|}{ OM (\%) } \\
\hline \multirow{2}{*}{2018} & IR & $2.54 \mathrm{~b}$ & $2.95 \mathrm{a}$ & $2.95 \mathrm{a}$ & $2.99 a$ & $2.45 b$ & \multirow{2}{*}{0.0002} & $<00001$ & 00009 \\
\hline & $\mathrm{R}$ & $2.05 \mathrm{a}$ & $2.11 \mathrm{a}$ & $2.27 \mathrm{a}$ & $2.26 \mathrm{a}$ & $2.38 \mathrm{a}$ & & $<0.0001$ & 0.0009 \\
\hline 2019 & IR & $3.03 \mathrm{bc}$ & $3.10 a b$ & $3.07 \mathrm{abc}$ & $2.82 \mathrm{c}$ & $3.31 \mathrm{a}$ & חרחת ח & ח 1630 & ה10200 \\
\hline 2015 & $\mathrm{R}$ & $2.70 \mathrm{a}$ & $2.89 a$ & $2.86 a$ & $2.83 a$ & $2.73 \mathrm{a}$ & $0.00<0$ & $0.10<0$ & 0.0210 \\
\hline
\end{tabular}

Means followed by the same lowercase letter in a row do not differ by Tukey's test $(p \geq 0.05)$. 
$\mathrm{Mg}^{2+}$ showed no significant difference between treatments in 2018; however, in 2019, treatments in SV and GLY were superior to coverage with BRARU in the inter-row orchard, and BRABR and GLY treatments were superior to SV in the planting row (Table 1). In all treatments, $\mathrm{Mg}^{2+}$ content was greater than $2.0 \mathrm{cmol}_{\mathrm{c}} \mathrm{dm}^{-3}$, which is considered very high by Moreira et al. (2019). This can be explained by the lower absorption of $\mathrm{Mg}^{2+}$ by the vegetative coverings of the SV and GLY treatments. However, although the levels of $\mathrm{Mg}^{2+}$ in the soil decreased in the first years of brachiaria cultivation, we emphasize that cover crops conduct nutrient cycling, releasing this nutrient to the soil in the long term.

The potassium content in inter-rows of the orchard was higher in the BRABR treatment in 2018 and BRADC in 2019 compared to the other treatments (Table 1). It is worth mentioning that, in all treatments, the potassium content was higher than $0.45 \mathrm{cmol}$ $\mathrm{dm}^{-3}$, which is classified as very high according to Moreira et al. (2019). The higher $\mathrm{K}^{+}$content in treatments with brachiaria can be explained by the cycling of this nutrient by such plants, and in the planting line, the content was lower because the requirement for this nutrient by citrus plants is high, and the root density of citrus plants is greater in the row than in the inter-row (Barbosa, Souza, Jorge, Leão, \& Campos, 2014). Similar results were obtained by Azevedo et al. (2020) in Tahiti lime orchards grafted on flying dragon trifoliate [Poncirus trifoliata var. monstrosa (T. Ito) Swingle], in which higher concentrations of $\mathrm{K}^{+}$in the soil were found in treatments with the presence of mulch of $U$. ruziziensis, and have been reported for other fruiting plants, such as apple trees, using SV as a cover crop (Oliveira et al., 2016).
The $\mathrm{P}$ content did not exhibit a significant difference between the treatments in 2018. However, in 2019, although there was no significant difference in the planting row, there was an effect in inter-rows, in which the phosphorus content was higher in the BRABR treatment than in the other treatments. In general, the values indicated high concentrations for the soil characteristics in the present study (clay texture) according to the classes defined by Moreira et al. (2019). Although only an effect of BRABR was found in 2019, it should be noted that $P$ has low mobility and is easily adsorbed on soil colloids; thus, these cover crops can contribute to the cycling and supply of this nutrient as was the case with BRABR. This result is caused by the efficiency of $P$ acquisition and use among forages because grasses have an abundant root system, resulting in greater production of root dry mass (Haling et al., 2016).

$\mathrm{H}+\mathrm{Al}$ had no interaction effect in 2018, with the lowest level observed in the SV treatment (Table 1). However, in 2019 there was an interaction effect, and in interrows of the orchard, the BRABR and BRARU treatments ( 3.5 and $3.4 \mathrm{cmol}_{\mathrm{c}} \mathrm{dm}^{-3}$ ) had higher $\mathrm{H}+\mathrm{Al}$ than the SV treatment. In the planting row, it was higher in SV than in BRABR and GLY. The higher potential acidity in the planting row, regardless of the management in inter-rows, may be caused by the greater absorption of nutrients by the citrus plants, releasing greater amounts of hydrogen into the rhizosphere, increasing $\mathrm{H}+\mathrm{Al}$.

The $\mathrm{pH}$ had no interaction effect in 2018; however, the SV treatment differed from the BRADC and GLY treatments, superior to both. In 2019, there was an interaction effect, and the SV treatment had the highest $\mathrm{pH}$ in 
the orchard inter-rows and the lowest $\mathrm{pH}$ in the planting row (Table 1). The results can be explained by the low nutrient absorption by the coverage provided by SV, generating a lower release of $\mathrm{H}^{+}$in the soil between the rows of the orchard. However, acidification under the canopy of orange trees can be caused by several factors, including the high amount of fertilizer applied in the planting line, leaching of nutrients into the soil, and the physiology of the orange trees, because such plants absorb large amounts of nutrients and release protons into the rhizosphere (Balota \& Auler, 2011).

The maximum of negative charges that the soil had $\left(\mathrm{CTC}_{\mathrm{pH}}\right)$ was analyzed together in 2018. Presented values in BRADC were higher than the values in GLY. In 2019, although significant, the interaction showed no difference between the treatments. The occurrence of little or no difference between the different cover crops is because of the first years of cultivation in the orchard, which is in line with that reported by Sharma, Irmak and Padhi (2018). They cultivated corn and soybeans with different cover crops and observed differences in CTC only after a long trial period, starting in 2002 and ending in 2015.

Base saturation (V\%) in 2018 was analyzed together, resulting in SV values higher than the BRABR and BRADC values. In 2019, there was an interaction effect, and in the orchard inter-rows, the SV treatment was superior to BRABR; however, in the planting row, the BRABR and GLY treatments were superior to the SV treatment. It is worth mentioning that, in general, the base saturation of treatments varied between the high (51.7 to $70.0 \%)$ and very high (>70\%) classes, corroborating the classification by Moreira et al. (2019). Additionally, higher base saturation values with the use of SV compared to soil without vegetation have also been reported in coffee crops (Carmo et al., 2011). In contrast, Sousa, Medeiros, Dalla Rosa, Mafra and Sousa Mendes (2017), who studied different vegetation covers, found no difference in base saturation between SV and brachiaria after 1 year of cultivation.

Regarding $\mathrm{OM}$, the values in the planting line and the inter-row were analyzed separately for the 2 years. In 2018, the lowest levels of OM were observed in the SV treatment in the inter-row, whereas in the planting row, there was no difference between the treatments. In 2019, higher OM values were observed in the SV treatment and lower values in the GLY treatment in the inter-rows, whereas in the planting row, there was no difference between the treatments. These results indicate that the different coverings used in this experiment determine the quantity and quality of organic residues present in the soil because they directly influence organic matter dynamics. Therefore, the GLY treatment was inferior in the organic matter content in inter-rows of the orchard in 2019 because this treatment has low vegetation coverage. Thus, despite the changes in organic matter stocks being slow and we had a short experimental period, which according to Baveye et al. (2018) and Bortolon, Mielniczuk, Tornquist, Lopes and Fernandes (2009), makes it difficult to visualize the OM behavior in the medium and long term in the soil, promising results were observed even in the first years of implementation of this experiment. This has also been observed in other cultures, such as olive trees (Bechara, Papafilippaki, Doupis, Sofo, \& Koubouris, 2018) and vines (López-Vicente, Calvo-Seas, Álvarez, \& Cerdà, 2020). 
Soil microbiological analysis

For CBM, the highest values were observed in the BRABR and BRADC treatments (Table 2). This effect is explainable because these two species have greater production of dry mass and root systems, which are directly reflected in the amount of organic substrates available for mineralization processes and high soil microbiological activity (Freitas et al., 2018; Simon et al., 2019). It is important to emphasize that the high levels of CBM are directly related to the availability of nutrients and the amount of microorganisms present in the soil, corroborating Bongiorno et al. (2019), who reported that nutrients immobilized by microbial biomass are in a more labile form for the target culture.

\section{Table 2}

Nitrogen (NBM) and carbon (CBM) from soil microbial biomass, basal soil respiration, and soil metabolic quotient in a Natal orange orchard under different soil cover. BRABR: U. brizantha, BRADC: U. decumbens, BRARU: $U$. ruziziensis, GLY: Glyphosate in total area, SV: Spontaneous vegetation in the row (R) and inter-rows (IR) of planting in 2018 and 2019 (Londrina/PR, 2019)

\begin{tabular}{|c|c|c|c|c|c|c|c|c|}
\hline \multirow{3}{*}{ Cover } & \multicolumn{4}{|c|}{ NBM (mg N kg ${ }^{-1}$ of soil) } & \multicolumn{4}{|c|}{ CBM (mg C kg ${ }^{-1}$ of soil) } \\
\hline & \multicolumn{2}{|c|}{2018} & \multicolumn{2}{|c|}{2019} & \multicolumn{2}{|c|}{2018} & \multicolumn{2}{|c|}{2019} \\
\hline & IR & $\mathrm{R}$ & IR & $\mathrm{R}$ & IR & $\mathrm{R}$ & IR & $\mathrm{R}$ \\
\hline BRABR & \multicolumn{2}{|c|}{$69.16 \mathrm{a}$} & $102.59 a$ & $52.03 \mathrm{a}$ & \multicolumn{2}{|c|}{$180.03 \mathrm{a}$} & \multicolumn{2}{|c|}{$410.03 a$} \\
\hline BRADC & \multicolumn{2}{|c|}{$63.09 \mathrm{ab}$} & $86.31 \mathrm{ab}$ & $36.49 \mathrm{a}$ & \multicolumn{2}{|c|}{205.16 a } & \multicolumn{2}{|c|}{$394.48 a b$} \\
\hline BRARU & \multicolumn{2}{|c|}{$52.99 \mathrm{ab}$} & $100.67 \mathrm{a}$ & $50.79 a$ & \multicolumn{2}{|c|}{$116.06 \mathrm{~b}$} & \multicolumn{2}{|c|}{$380.85 \mathrm{bc}$} \\
\hline GLY & \multicolumn{2}{|c|}{$51.11 b$} & $58.09 \mathrm{~b}$ & $33.04 \mathrm{a}$ & \multicolumn{2}{|c|}{$142.89 b$} & \multicolumn{2}{|c|}{$371.24 \mathrm{c}$} \\
\hline \multirow[t]{2}{*}{ SV } & \multicolumn{2}{|c|}{$55.63 \mathrm{ab}$} & $49.72 b$ & $53.82 \mathrm{a}$ & \multicolumn{2}{|c|}{$115.84 b$} & \multicolumn{2}{|c|}{$374.04 \mathrm{c}$} \\
\hline & \multicolumn{8}{|c|}{$p$-value } \\
\hline$A \times B$ & \multicolumn{2}{|c|}{0.0500} & \multicolumn{2}{|c|}{0.0192} & \multicolumn{2}{|c|}{0.1940} & \multicolumn{2}{|c|}{0.4511} \\
\hline Position (A) & \multicolumn{2}{|c|}{$<0.0001$} & \multicolumn{2}{|c|}{0.0006} & \multicolumn{2}{|c|}{0.0004} & \multicolumn{2}{|c|}{0.0202} \\
\hline Cover (B) & \multicolumn{2}{|c|}{0.0210} & 0.0 & & $<0$. & & & \\
\hline & & $\lg \mathrm{C}-\mathrm{CC}$ & $\mathrm{kg}^{-1} \mathrm{~g}$ soil & & & (mg C-C & $\mathrm{g}^{-1} \mathrm{BMS}$ & $\left.h^{-1}\right)$ \\
\hline Cover & & & 20 & & & & & \\
\hline & IR & $\mathrm{R}$ & IR & $\mathrm{R}$ & IR & $\mathrm{R}$ & IR & $\mathrm{R}$ \\
\hline BRABR & $34.5 b$ & $35.5 a$ & $16.1 \mathrm{a}$ & $10.8 \mathrm{~b}$ & $1.83 a b$ & $2.28 \mathrm{~b}$ & $3.80 \mathrm{a}$ & $2.71 b$ \\
\hline BRADC & $37.7 \mathrm{~b}$ & $35.9 a$ & $19.2 \mathrm{a}$ & $10.9 \mathrm{~b}$ & $1.71 \mathrm{abc}$ & $2.07 \mathrm{~b}$ & $4.78 \mathrm{a}$ & $2.80 \mathrm{~b}$ \\
\hline BRARU & $50.7 \mathrm{a}$ & 34.9 a & $14.8 \mathrm{a}$ & $17.5 \mathrm{a}$ & $1.30 \mathrm{bc}$ & $1.76 \mathrm{~b}$ & $3.82 a$ & $4.68 \mathrm{a}$ \\
\hline GLY & $16.7 \mathrm{c}$ & $19.1 \mathrm{~b}$ & $16.9 a$ & $11.2 \mathrm{~b}$ & $3.67 \mathrm{a}$ & $2.68 \mathrm{a}$ & $4.57 \mathrm{a}$ & $3.04 \mathrm{~b}$ \\
\hline SV & $16.1 \mathrm{c}$ & $14.0 \mathrm{~b}$ & $13.8 \mathrm{a}$ & $9.2 \mathrm{~b}$ & $1.36 \mathrm{c}$ & $1.32 \mathrm{~b}$ & $3.63 \mathrm{a}$ & $2.49 \mathrm{~b}$ \\
\hline$A \times B$ & & & 0.0 & & 0.0 & & & \\
\hline Position (A) & & & 0.0 & & 0.5 & & & \\
\hline Cover (B) & & & 0.0 & & 0.0 & & & \\
\hline
\end{tabular}

Means followed by the same lowercase letter in a column do not differ by Tukey's test ( $p \geq 0.05)$. 
In 2018, NBM presented a higher value in the BRABR treatment and differed from the GLY treatment, which presented the lowest NBM value (Table 2). In 2019, in the interrows of the orchard, it was observed that the BRABR, BRADC, and BRARU treatments had the highest NBM contents and differed from the GLY and SV treatments. However, there was no difference between treatments in the planting line in 2019 because the prevalence of cover crops was only in the inter-rows of the orchard.

The change in NBM in treatments with brachiaria cover can be explained by the influence of these species on soil dynamics, although they do nothave the same mechanism as leguminous plants for biological nitrogen fixation, as reported by Vázquez et al. (2020). However, high levels of organic matter, total $\mathrm{N}$, and higher carbon of microbial biomass, which are considered the main drivers of soil $\mathrm{N}$ mineralization and inorganic $\mathrm{N}$ immobilization, were found in the rhizosphere of brachiaria genotypes with a high capacity for biological inhibition of nitrification (Horrocks et al. 2019). This could be considered an indicator of greater decomposition of soil organic matter and ammonification (Teutscherova et al., 2019). Thus, studies have shown that root exudates from certain Urochloa genotypes can inhibit ammonium oxidation in an in vitro bioassay with Nitrosomonas and reduce net nitrification in soils, a phenomenon called biological nitrification (BNI). This has been associated with low nitrate content of soil and reduction of nitrogen $(\mathrm{N})$ losses in pasture systems (Vázquez et al., 2020), which probably occurred in the present study because there was an increase in NBM content.

In the variable basal respiration (RB), there was a significant interaction effect in
2018 and 2019 (Table 2), with higher values in the line and inter-rows in the management with the brachiaria species compared to management with only GLY and SV in 2018. In 2019, only BRARU was superior to the other treatments in the planting row and interrows. There was no difference between the treatments. These results are justified, even if high RB values are related to stress conditions and low efficiency in converting organic $C$ to CBM because of the higher energy expenditure to keep the microorganisms in the soil alive. Low values indicate low specific activity of the microbiota of the soil (L. S. D. Almeida et al., 2016) when the implementation of cover crops is recent; therefore, it indicates that the soil is still establishing itself for a new equilibrium condition in its microbiological community. When systems become more stable, basal soil respiration decreases (Araújo et al., 2019).

For the metabolic quotient $\left(q \mathrm{CO}_{2}\right)$ in 2018, GLY was superior to the other treatments in the planting row and inter-row; however, GLY differed only from the BRARU and SV treatments in the inter-rows of the orchard. In 2019, BRARU was superior to the other treatments in the planting row, and there was no difference between the treatments in the inter-rows of the orchard. The plots with BRABR, BRADC, and GLY presented higher $q \mathrm{CO}_{2}$ in the line than the other treatments in 2018; however, only GLY differed from the other treatments in inter-rows. Although the latter had higher $q \mathrm{CO}_{2}$ values, it is noteworthy that the accumulation of $\mathrm{OM}$ is related to the generation of phytomass by the plants. Thus, although presenting higher values of $q \mathrm{CO}_{2}$, the treatment with glyphosate may not present an increase in the OM content because such management does not represent cover crops but only mulch from desiccated SV. 
Additionally, high values of $q \mathrm{CO}_{2}$ can indicate stressful environmental conditions because microbial biomass requires more carbon for maintenance (Mendes et al., 2009).

\section{Cluster analysis and principal components}

In Figure 1, the dissimilarity dendrogram obtained from the standardized data matrix of the 13 parameters evaluated in the 2 years can be seen. Our goal was to assess the similarity between the proposed managements. To analyze the similarity in the results of the years, a Mantel correlation between the dissimilarity matrices was performed, obtaining a value of $r=0.62$, demonstrating that the treatments behaved similarly. Through the analysis, five distinct clusters formed in 2018 (Cluster A: SV-R; Cluster B: BRABR-R, BRADC-R, GLY-R, and BRARU-R; Cluster C: BRARU-IR; Cluster D: BRABR-IR and BRADC-IR; and Cluster E: GLYIR and SV-IR) and four clusters in 2019 (Cluster A: BRABR-IR, BRADC-IR; Cluster B: BRARU-IR; GLY-IR, and SV-IR; Cluster C: BRARU-R; and Cluster D: GLY R, BRABR-R, BRADC-R, and SV-R).
2018

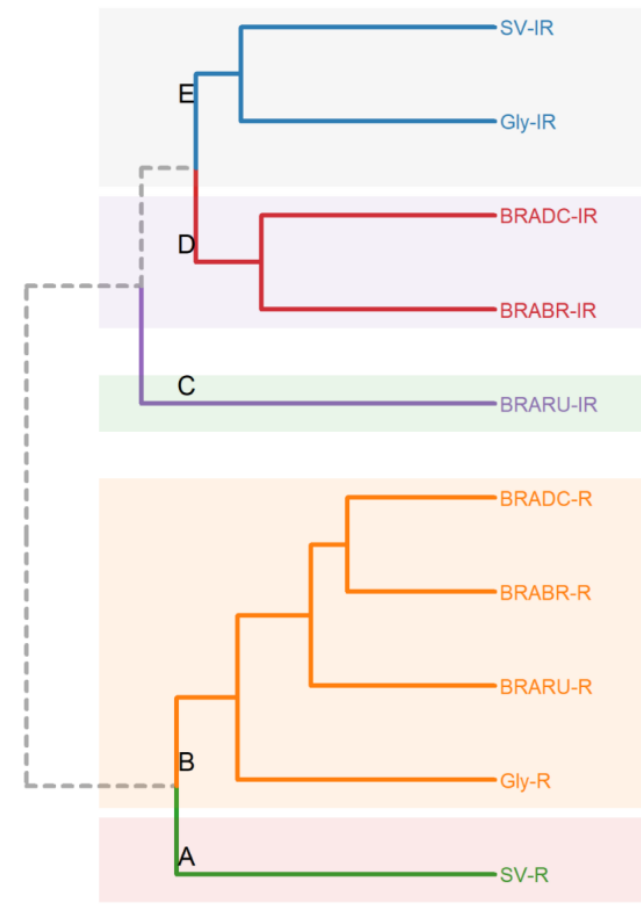

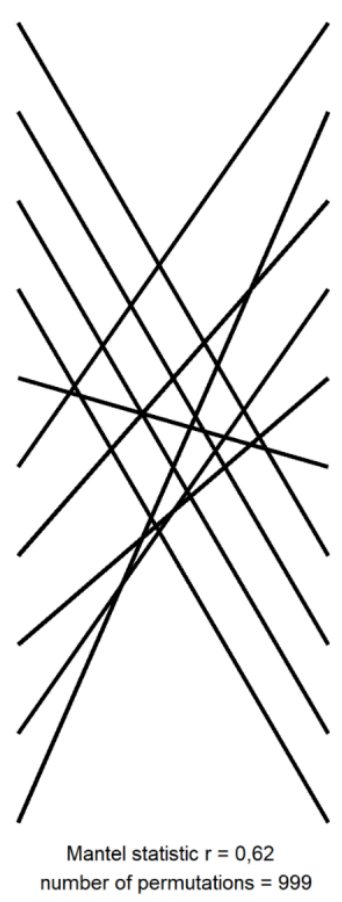

2019

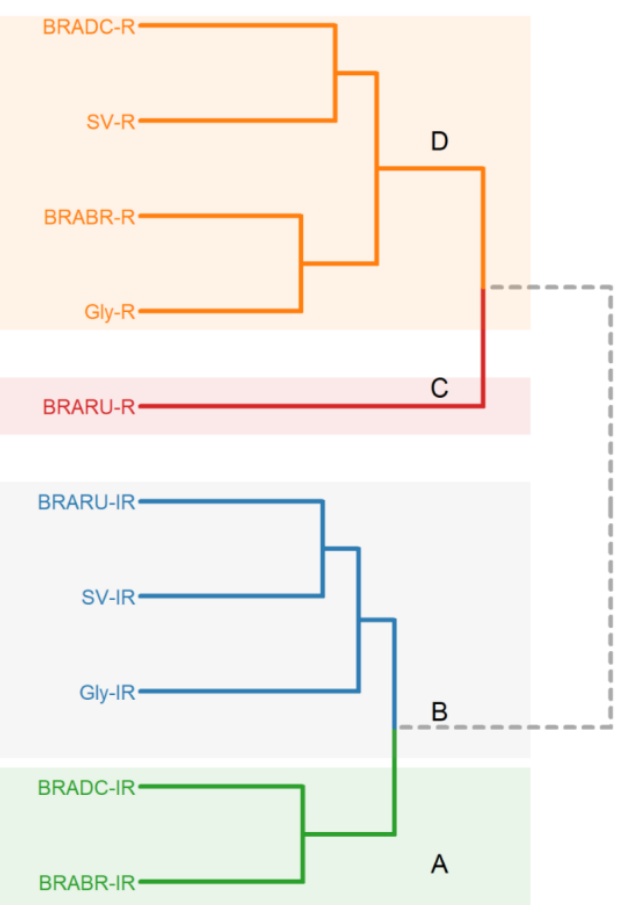

Figure 1. Dendrogram of dissimilarity considering the chemical and microbiological attributes of soil from samples of different cover. BRABR: U. brizantha; BRADC: $U$. decumbens; BRARU: $U$. ruziziensis; GLY: Glyphosate in the total area; SV: Spontaneous vegetation in the inter-rows (IR) and rows (R) in a Natal orange orchard in 2018. 
The clustering of $U$. brizantha and $U$. decumbens species in inter-rows of the orchard, mainly in 2019, showed that such treatments showed similar responses to changes in soil properties. Corroborating the studies by Balota and Auler (2011), who reported that the introduction of cover crop species in the soil, when properly managed, can benefit the soil and the main crop. However, GLY-R remained in the same group of samples from the planting line of treatments with the brachiaria species (Cluster B in 2018 and Cluster D in 2019), suggesting that the brachiaria did not influence the soil attributes in the brachiaria line planting in the orchard. This result was expected because the mulch generated by the inter-row mowing was not deposited on the planting line, and although the cover crops show lateral root growth, it may not have presented short-term beneficial effects on the recent implementation of soil quality. These results are similar to those of Bremer, Victoria, Mourão, Menezes and Canali (2008).

The weights between the variables and the main components allowed us to characterize the variables that discriminated the most in the formation and differentiation of soils (Figure 2), confirming the cluster analysis for the studied managements. Therefore, the first and second principal components were sufficient to explain $44.0 \%$ and $12.7 \%$ (2018) and $49.6 \%$ and $13.1 \%$ (2019) of the total variance, respectively. Thus, when analyzing loads of the main components and the correlation between the parameters with the latent variables $\mathrm{CP} 1$ and $\mathrm{CP} 2$ (Figure 2), for CP1, the parameters calcium and magnesium were the most important in 2018, also reflected in $\mathrm{CTC}_{\mathrm{pH} 7}$, the sum of bases, and base saturation. However, for CP2, the best correlation occurred with the basal soil respiration parameter, reflecting the metabolic quotient $\left(q \mathrm{CO}_{2}\right)$. In 2019, the parameters $\mathrm{K}^{+}$and $\mathrm{Mg}^{2+}$ were the most important for CP1, whereas, for CP2, the best correlation occurred with the carbon and nitrogen of the microbial biomass in the soil. These results show that microbiological parameters are better correlated with the second main component than the first.

Analysis of the biplot scatter plot of the main components with the first two latent variables for 2018 (Figure 2A) showed that cluster $D$ was formed by the brachiaria species in inter-rows of the orchard, except for BRARU, which was the best positioned in most of the studied variables. However, there was a weak relationship with the latent variable $\mathrm{CP} 2$, indicating a weak relationship between management and the microbiological attributes studied. Furthermore, the samples from cluster B presented values negatively related to the data vectors, which possibly characterizes detrimental management of soil quality in terms of chemical aspects, mainly calcium and magnesium, and microbiological aspects such as basal respiration and metabolic quotient. In 2019, cluster B (GLYIR, BRARU-IR, and SV-IR) showed a negative association with most parameters, except for calcium and magnesium content, which were positively associated with the cluster. 

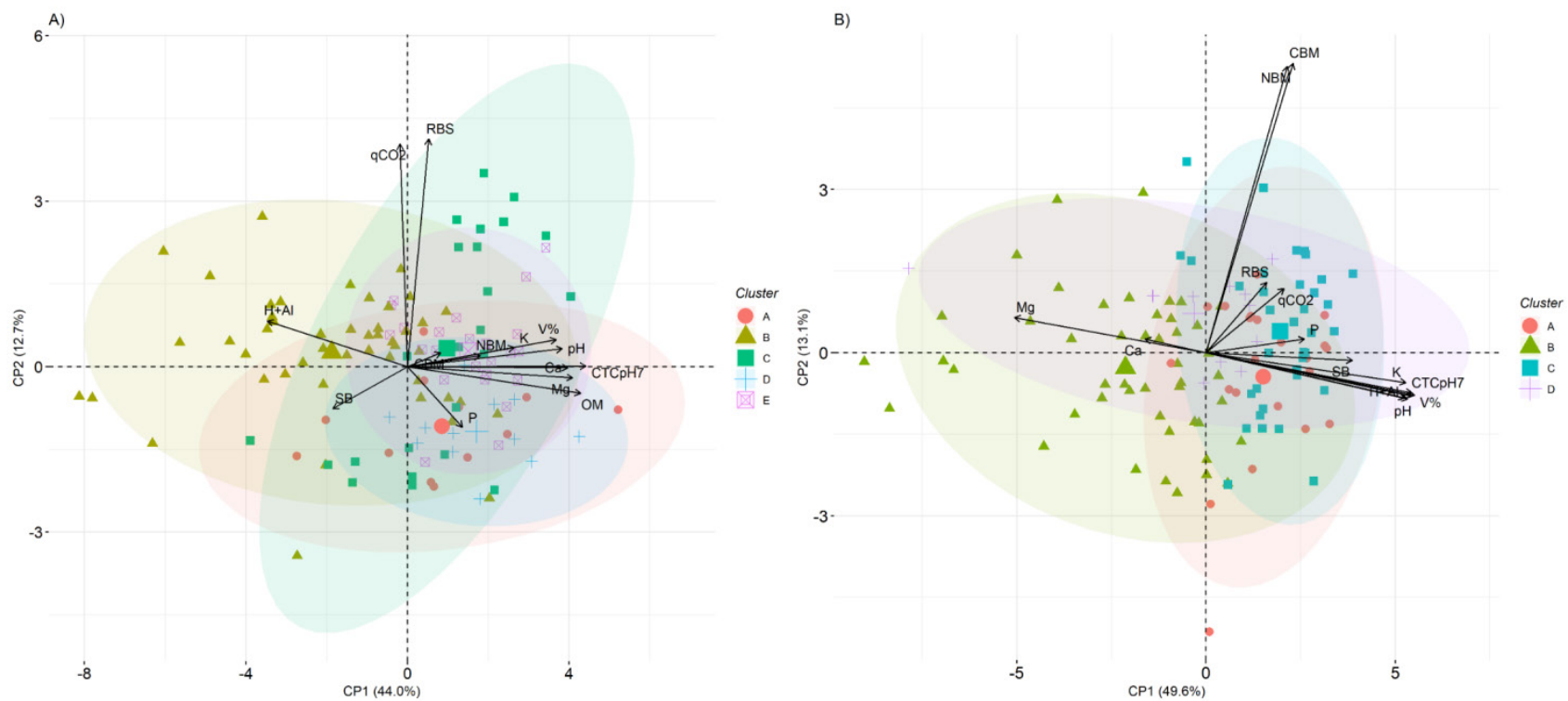

Figure 2. Biplot plot of main components of chemical and microbiological attributes of soil with different vegetation cover in the inter-rows in a Natal orange orchard in 2018 (A) and 2019 (B). Calcium (Ca), magnesium (Mg), potassium (K), potential acidity $(\mathrm{H}+\mathrm{Al})$, pH, phosphorus (P), CTC $\mathrm{pH}^{\prime}$ base saturation (V\%), organic matter (OM), nitrogen (NBM), and carbon (CBM) from soil microbial biomass, soil basal respiration (RBS), and soil metabolic quotient $\left(q \mathrm{CO}_{2}\right)$.

The change in the management of the orchard rows by introducing brachiaria species provided evidence that these cover crops provided benefits to the terrestrial environment and the change in the attributes of soil quality, in agreement with the studies by Merino-Martín et al. (2021). These authors also suggest that any change in the ecosystem, especially changes in land use, such as the mechanical action of soil preparation, the use of management inputs, and implementation of cover crops, can have major effects on microbial communities (Merino-Mártin et al., 2021).

\section{Vegetative development analysis}

There was no significant difference in height, width, or canopy volume of Natal orange trees in the 2 years studied. The height in 2018 and 2019 averaged 1.16 and $1.27 \mathrm{~m}$, whereas the width was 0.88 and $0.96 \mathrm{~m}$, respectively. For the crown volumes in 2018 and 2019, 2.54 and $3.25 \mathrm{~m}^{3}$ were observed, respectively. Even when using plant species in inter-rows of the orchard for two consecutive years, this period was not sufficient for significant changes in the vegetative development of the orange trees. Such results do not corroborate Azevedo et al. (2020) studying the use of $U$. ruziziensis, an ecological cutter, and glyphosate, in which they observed a difference in the development of Tahiti acid lime plants in the first years after the implementation of cover crops. However, Azevedo et al. (2012) did not observe an increase in the productivity of Pêra oranges (Citrus sinensis L.) when they compared different cover crops in inter-rows of the orchard. 


\section{Conclusions}

$U$. brizantha and $U$. ruziziensis grown between citrus rows improved the chemical and microbiological attributes of the soil.

The introduction of brachiaria species to inter-rows of the sweet orange orchard was positive; however, the brachiaria species introduced in inter-rows of the orchard did not benefit the chemical and microbiological attributes of the planting line.

Treatments with SV and glyphosate in the total area were negatively related to the variable responses, characterizing the management that affects soil quality in a Natal orange orchard.

\section{Acknowledgments}

To the Coordenação de Aperfeiçoamento de Pessoal de Nível Superior (Capes) and to the Conselho Nacional de Desenvolvimento Científico e Tecnológico (CNPq), for granting a scholarship.

\section{References}

Almeida, D. S., \& Rosolem, C. A. (2016). Ruzigrass grown in rotation with soybean increases soil labile phosphorus. Agronomy Journal, 108(6), 2444-2452. doi: 10.2134/agronj2015.0478

Almeida, L. S. D., Ferreira, V. A. S., Fernandes, L. A., Frazão, L. A., Oliveira, A. L. G., \& Sampaio, R. A. (2016). Indicadores de qualidade do solo em cultivos irrigados de cana-deaçúcar. Pesquisa Agropecuária Brasileira, 51(9), 1539-1547. doi: 10.1590/S0100204X2016000900053
Araújo, F. S., Barroso, J. R., Freitas, L. D. O., Teodoro, M. S., Souza, Z. M. D., \& Torres, J. L. (2019). Chemical attributes and microbial activity of soil cultivated with cassava under different cover crops. Revista Brasileira de Engenharia Agrícola e Ambiental, 23(8), 614-619. doi: 10.1590/1807-1929/agriambi.v23n8 p614-619

Azevedo, F. A., Almeida, R. F., Martinelli, R., Próspero, A. G., Licerre, R., Conceição, P. M.,... Mattos, D. (2020). No-Tillage and high-density planting for tahiti acid lime grafted onto flying dragon trifoliate orange. Frontiers in Sustainable Food Systems, 4(1), 1-14, 2020. doi: 10.3389/ fsufs. 2020.00108

Azevedo, F. A., Rossetto, M. P., Schinor, E. H., Martelli, I. B., \& Pacheco, C. A. (2012). Influência do manejo da entrelinha do pomar na produtividade da laranjeira'Pera'. Revista Brasileira de Fruticultura, 34(1), 134-142. doi: 10.1590/S0100-29 452012000100019

Balota, E. L., \& Auler, P. A. M. (2011). Soil microbial biomass under different management and tillage systems of permanent intercropped cover species in an orange orchard. Revista Brasileira de Ciência do Solo, 35(6), 1873-1883. doi: 10.1590/S0100-06832011000600004

Baptistella, J. L. C., Andrade, S. A. L. de, Favarin, J. L., \& Mazzafera, P. (2020). Urochloa in tropical agroecosystems. Frontiers in Sustainable Food Systems, 4(1), 119. doi: 10.3389/fsufs.2020.00119

Barbosa, R. S., Souza, Z. M., Jorge, L. A. C., Leão, H. C., \& Campos, M. C. C. (2014). Atributos físicos do solo e do sistema radicular em citros sob diferentes preparos. Amazonian Journal of Agricultural and Environmental Sciences, 57(4), 342-350. doi: 10.4322/ rca.1505 
Baveye,P.C., Otten, W., Kravchenko,A., BalseiroRomero, M., Beckers, É., Chalhoub, M.,... Vogel, H. J. (2018). Emergent properties of microbial activity in heterogeneous soil microenvironments: different research approaches are slowly converging, yet major challenges remain. Frontiers in Microbiology, 9(1), 1929. doi: 10.3389/ fmicb.2018.01929

Bechara, E., Papafilippaki, A., Doupis, G., Sofo, A., \& Koubouris, G. (2018). Nutrient dynamics, soil properties and microbiological aspects in an irrigated olive orchard managed with five different management systems involving soil tillage, cover crops and compost. Journal of Water and Climate Change, 9(4), 736747. doi: 10.2166/wcc.2018.082

Bongiorno, G., Bünemann, E. K., Oguejiofor, C. U., Meier, J., Gort, G., Comans, R.,... Goede, R. de. (2019). Sensitivity of labile carbon fractions to tillage and organic matter management and their potential as comprehensive soil quality indicators across pedoclimatic conditions in Europe. Ecological Indicators, 99(1), 38-50. doi: 10.1016/j.ecolind.2018.12.008

Bortolon, E. S. O., Mielniczuk, J., Tornquist, C. G., Lopes, F., \& Fernandes, F. F. (2009). Simulação da dinâmica do carbono e nitrogênio em um Argissolo do Rio Grande do Sul usando modelo Century. Revista Brasileira de Ciência do Solo, 33(6), 1635-1646. doi: 10.1590/S010006832009000600012

Bremer, H., Neto, Victoria, R., Fo., Mourão F. A. A., Fo., Menezes, G. M. de, \& Canali, E. (2008). Estado nutricional e produção de laranjeira "Pêra" em função da vegetação intercalar e cobertura morta. Pesquisa Agropecuária Brasileira, 43(1), 29-35. doi: 10.1590/S0100-204X2008000100005
Bremer, J. M. (1965). Total nitrogen In C. A. Black, D. D. Eions, J. L. White, L. E. Ensminger, F. E. Clark, \& R. C. Dinauer, Methods of soil analysis (pp. 1149-1178). Madison, Wisconsin: Am. Soc. Agron.

Byrnes, R. C., Nùñez, J., Arenas, L., Rao, I., Trujillo, C., Alvarez, C., Arango, J., Rasche, F., \& Chirinda, N. (2017). Biological nitrification inhibition by Brachiaria grasses mitigates soil nitrous oxide emissions from bovine urine patches. Soil Biology and Biochemistry, 107(1), 156163. doi: 10.1016/j.soilbio.2016.12.029

Carmo, D. L., Nannetti, D. C., Dias, M. S., Jr., Santo, D. J. E., Lacerda, T. M., \& Albuquerque, A. D. (2011). Contribution of spontaneous plants on the physicochemical properties of Latosol and in the nutrition of the coffee plant (Coffea arabica L.). Coffee Science, 6(3), 233-241.

Empresa Brasileira de Pesquisa Agropecuária (2018). Sistema brasileiro de classificação de solos (5a ed.). Brasília: EMBRAPA CNPS.

Feije, F., \& Anger, V. (1972). Spot test in inorganic analysis. Analytica Chimica Acta, 149(1), 363-367.

Food and Agriculture Organization (2017). Conservation agriculture. Retrieved from http://www.fao.org/ag/ca/\$

Food and Agriculture Organization of the United Nations (2019). FAOSTAT. Retrieved from http://www.fao. org/faostat/en/\#data/QC

Freitas, M. A. M., Silva, D. V., Guimarães, F. R., Leal, P. L., Souza Moreira, F. M. de, Silva, A. A. da, \& Freitas Souza, M. de. (2018). Biological attributes of soil cultivated with corn intercropped with Urochloa brizantha in different plant arrangements with and without herbicide application. Agriculture, Ecosystems \& Environment, 254(1), 3540. doi: 10.1016/j.agee.2017.10.026 
Haling, R. E., Yang, Z., Shadwell, N., Culvenor, R. A., Stefanski, A., Ryan, M. H.,... Simpson, R. J. (2016). Growth and root dry matter allocation by pasture legumes and a grass with contrasting external critical phosphorus requirements. Plant and Soil, 407(1), 67-79. doi: 10.1007/s11104-0162808-2

Horrocks, C. A., Arango, J., Arevalo, A., Nuñez, J., Cardoso, J. A., \& Dungait, J. A. J. (2019). Smart forage selection could significantly improve soil health in the tropics. Science of the Total Environment, 688(1), 609-621. doi: 10.1016/j.scitotenv.2019.06.152

Instituto de Desenvolvimento Rural do Paraná (2019). Médias históricas da estação meteorológica de Londrina. Recuperado de http://www.iapar.br/arquivos/Image/ monitoramento/Medias_Historicas/ Londrina.htm

Janegitz, M. C., Inoue, B. S., \& Rosolem, C. A. (2013). Formas de fósforo no solo após o cultivo de braquiária e tremoço branco. Ciência Rural, 43(8), 1381-1386. doi: 10.1590/S0103-84782013000800007

Jenkinson, D. S., \& Powlson, D. S. (1976). The effects of biocidal treatments on metabolism in soil II. Gamma irradiation, autoclaving, air-drying and fumigation. Soil Biology and Biochemistry, 8(3), 179188. doi: 10.1016/0038-0717(76)90005-5

López-Vicente, M., Calvo-Seas, E., Álvarez, S., \& Cerdà, A. (2020). Effectiveness of cover crops to reduce loss of soil organic matter in a rainfed vineyard. Land, 9(7), 230. doi: 10.3390/land9070230

Martinelli, R., Monquero, P. A., Fontanetti, A., Conceição, P. M., \& Azevedo, F. A. (2017). Ecological mowing: An option for sustainable weed management in young citrus orchards. Weed Technology, 31(2), 260-268. doi: 10.1017/wet.2017.3
Martins, D., Gonçalves, C. G., \& Silva, A. C. D., Jr., (2016). Coberturas mortas de inverno e controle químico sobre plantas daninhas na cultura do milho. Revista Ciência Agronômica, 47(4), 649-657. doi: 10.5935/1806-6690.20160078

Martorano, L. G., Bergamaschi, H., Dalmago, G. A., Faria, R. T. D., Mielniczuk, J., \& Comiran, F. (2009). Indicadores da condição hídrica do solo com soja em plantio direto e preparo convencional. Revista Brasileira de Engenharia Agrícola e Ambiental, 13(4), 397-405. doi: 10.1590/S1415-43 662009000400005

Mattos, D., Jr., Negri, J. D. de, Pompeu, J., Jr., Ghilardi, A. A., Azevedo, F. A., \& Bastianel, M. (2014). Citros: principais informações e recomendações de cultivo. In A. T. E. Aguiar, C. Gonçalves, M. E. A. G. Z. Pateniani, M. L. S. Tucci, \& C. E. F. Castro (Eds.), Instruções agrícolas para as principais culturas econômicas (7a ed., pp. 140-149). (Boletim IAC, 200). Campinas: Instituto Agronômico.

Mendel, K. (1956). Roostock-scion relationships in Shamouti trees on light soil. Ktavim, 6(1), 35-38.

Mendes, I. D. C., Cunha, M. H. da, Reis, F. B. dos, Jr., Fernandes, M. F., Chaer, G. M., Mercante, F. M., \& Zilli, J. E. (2009). Bioindicadores para avaliação da qualidade dos solos tropicais: utopia ou realidade? Planaltina, Distrito Federal: EMBRAPA CerradosDocumentos (INFOTECA-E).

Merino-Martín, L., Stokes, A., Gweon, H. S., Moragues-Saitua,L.,Staunton,S.,Plassard, C.,... Griffiths, R. I. (2021). Interacting effects of land use type, microbes and plant traits on soil aggregate stability. Soil Biologyand Biochemistry, 154(1), 108072. doi: 10.1016/j.soilbio.2020.108072 
Moreira, A., Motta, A. C. V., Costa, A., Muniz, A. S., Cassol, L. C., Zanão, L. A., Jr.,... Pauletti, V. (2019). Manual de adubação e calagem para o estado do Paraná 2a edição. Curitiba: Sociedade Brasileira de Ciência do Solo, Núcleo Estadual do Paraná.

Nuñez, J., Arevalo, A., Karwat, H., Egenolf, K., Miles, J., Chirinda, N.,... Arangoet, J. (2018). Biological nitrification inhibition activity in a soil-grown biparental population of the forage grass, Brachiaria humidicola. Plant Soil, 426(1), 401-411. doi: 10.1007/ s11104-018-3626-5

Oliveira, B. S., Ambrosini, V. G., Trapp, T., Santos, M. A. dos, Sete, P. B., Lovato, P. E.,... Brunetto, G. (2016). Nutrition, productivity and soil chemical properties in an apple orchard under weed management. Nutrient Cycling in Agroecosystems, 104(1), 247-258. doi: 10.1007/s10705016-9769-y

R Development Core Team (2019). A language and environment for statistical computing. Vienna, Austria: R Foundation for Statistical Computing. Retrieved from http://www.R-project.org/

Ribeiro, H., Jaime, P. C., \& Ventura, D. (2017). Alimentação e sustentabilidade. Estudos Avançandos, 31(89), 185-198. doi: 10.15 90/s0103-40142017.31890016

Rosolem, C. A., Ritz, K., Cantarella, H., Galdos, M. V., Hawkesford, M. J., Whalley, W. R., \& Mooney, S. J. (2017). Enhanced plant rooting and crop system management for improved $\mathrm{N}$ use efficiency. Advances in Agronomy, 146(1), 205-239. doi: 10.1016/ bs.agron.2017.07.002

Sharma, V., Irmak, S., \& Padhi, J. (2018). Effects of cover crops on soil quality: Part II. Soil exchangeable bases (potassium, magnesium, sodium, and calcium), cation exchange capacity, and soil micronutrients (zinc, manganese, iron, copper, and boron). Journal of Soil and Water Conservation, 73(6), 652-668. doi: 10.2489/jswc.73.6.652

Silva, B. M., Oliveira, G. C., Serafim, M. E., Silva, É. A., Guimarães, P. T. G., Melo, L. B. B.,... Curi, N. (2019). Soil moisture associated with least limiting water range, leaf water potential, initial growth and yield of coffee as affected by soil management system. Soil \& Tillage Research, 189(1), 36-43. doi: 10.1016/j.still.2018.12.016

Silva, E. E., Azevedo, P. H. S. de, \& De-Polli, H. (2007). Determinação da respiração basal (RBS) e quociente metabólico do solo $\left(q \mathrm{CO}_{2}\right)$. (Comunicado Técnico, INFOTECA-E). Seropédica, Rio de Janeiro: EMBRAPA Agrobiologia.

Simon, C. A., Lima, S. F. de, Cordeiro, M. S., Secco, V. A., Nacata, G., Silva, A. M. M.,... Silva Brasil, M. da. (2019). Cover crops as modifying agents of microbiological soil attribute. Australian Journal of Crop Science, 13(10), 1578. doi: 10.21475/ ajcs.19.13.10.p1723

Sousa, D. C. de, Medeiros, J. C., Dalla Rosa, J., Mafra, A. L., \& Sousa Mendes, W. de. (2017). Chemical attributes of agricultural soil after the cultivation of cover crops. Australian Journal of Crop Science, 11(11), 1497-1503. doi: 10.21475/ajcs.17.11.11. pne799

Tedesco, M. J., Gianello, C., Bissani, C. A., Bohnen, H., \& Volkweiss, S. J. (1995). Análises de solo, plantas e outros materiais (vol. 174). Porto Alegre: UFRGS.

Teutscherova, N., Vazquez, E., Arango, J., Arevalo, A., Benito, M., \& Pulleman, M. (2019). Native arbuscular mycorrhizal fungi increase the abundance of ammonia-oxidizing bacteria, but suppress nitrous oxide emissions shortly after urea application. Geoderma, 338(1), 493-501. doi: 10.1007/s0037 4-019-01353-y 
Vance, E. D., Brookes, P. C., \& Jenkinson, D. S. (1987). An extraction method for measuring soil microbial biomass C. Soil biology and Biochemistry, 19(6), 703-707. doi: 10.1016/0038-0717(87)90052-6

Vázquez, E., Teutscherova, N., Dannenmann, M., Töchterle, P., Butterbach-Bahl, K., Pulleman, M., \& Arango, J. (2020). Gross nitrogen transformations in tropical pasture soils as affected by Urochloa genotypes differing in biological nitrification inhibition (BNI) capacity. Soil Biologyand Biochemistry, 151(1), 108058. doi: 10.1016/j.soilbio.2020.108058
Walkley, A., \& Black, I. A. (1934). An examination of the Degtjareff method for determining soil organic matter, and a proposed modification of the chromic acid titration method. Soil Science, 37(1), 29-38. doi: 10.1097/00010694-193401000-00003

Welz, B., \& Sperling, M. (2008). Atomic absorption spectrometry. Weinheim: John Wiley \& Sons.

Willekens, K., Vandecasteele, B., Buchan, D., \& de Neve, S. (2014). Soil quality is positively affected by reduced tillage and compost in an intensive vegetable cropping system. Applied Soil Ecology, 82(1), 6171. doi: 10.1016/j.apsoil.2014.05.009 
